\title{
BIOCHEMICAL EVALUATION OF MEAT AND HAEMOLYMPH OF AFRICAN LAND SNAIL (ARCHACHATINAMARGINATA, SWAINSON) IN SOUTH-WEST NIGERIA
}

\author{
A.S. Kehinde ${ }^{1}$, *K.M. Adelakun², S.K. Halidu ${ }^{2}$, T.O. Babatunde ${ }^{3}$ and B.O. Fadimu ${ }^{1}$ \\ 1- Department of Wildlife Domestication and Conservation, Forestry Research Institute of Nigeria, P.M.B. \\ 5054, Jericho Hill, Ibadan Oyo State, Nigeria, 2- Department of Wildlife and Ecotourism, Federal College of \\ Wildlife Management, Forestry Research Institute of Nigeria, P.M.B. 268, New Bussa, Nigeria, 3- \\ Department of Forestry Technology, Federal College of Forestry of Forestry Research Institute of Nigeria,, \\ P.M.B. 5054, Jericho Hill, Ibadan Oyo State, Nigeria. \\ *Corresponding author: Kehinde Moruff Adelakun: e-mail: adelakunkehinde@gmail.com
}

Received: $04 / 08 / 2020$

Accepted: 04/10/2020

\section{SUMMARY}

This study evaluates the meat and haemolymph of Archachatinamarginata from Southwest Nigeria for its chemical contents. Forty-five African land snails(Archachatinamarginata,Swainson) were randomly allotted to three treatments (Adults, growers and snailets) at 5 snails each of three replicates, to evaluate biochemical qualities of meat (proximate, mineral and cholesterol) and haemolymph (mineral and cholesterol). The results obtained revealed highest $(p<0.05)$ dry matter $(79.25 \%)$, ether extract $(1.46 \%)$, ash $(1.34 \%)$ and Nitrogen Free Extract (59.28\%) for adult snail meat and least values for snailets. The same trend of variation was recorded for its mineral and cholesterol determinations. The mineral profile of the haemolymphdid not vary with growing stage, however, all cholesterol quantity and quality estimates were highest $(p<0.05)$ in adults and least in snailets (total cholesterol, HDL, LDL and LDL-HDL differential). Snail meat and haemolymph in the study area contained important nutrients for human nourishment and other consumptive purposes.

Keywords: Snail, proximate, cholesterol, biochemical, mineral

\section{INTRODUCTION}

The quality and quantity of meat consumed in a nation indicates the position of social and economic prosperity and a measurement of the worthiness status of a country or an individual (Ososanya, 2004). As a nation industrializes, the food intake pattern improves and there is a need to increase the production of good quality energy and protein resources.

It has been reported that low protein intake is an important factor responsible for retarded growth in children (Manary, 2013). FAO (2006) recommended daily intake of $8.0 \mathrm{~g}$ per $\mathrm{kg}$ of body weight as dietary protein allowance that could be provided from both animal and plant sources, most developing countries consume just one third of the value, which is below recommended daily allowance (Kehinde,2019). The Nigerian livestock industry is aggressively pursuing strategies to bridge the protein consumption gap, through governmental support intervention in the Bank of Industry and Central Bank loan provision (Ademoluet al., 2020).

Researchers and farmers are adopting multidisciplinary approaches to resolve the observed challenges by focusing on lesser known animals, such as rabbits, grasscutters, quails and snails (Omole, 2002). Snail farming and collection are now very popular in Nigeria, in order to meet the protein need of the rural and urban populace (Ademoluet al., 2009 and Kehinde, 2009).

Snail meat is nutritious and regarded as delicacy. It is aprime choice in hotels and restaurants due to its special taste (Akinnusiet al., 2019). It has been widely reported as a special meat for the treatment of hypertension and kidney related ailments (Omole, 2002).

Ebenebe(2000) has reported that snail is rich in protein, vitamins and omega-3- fatty acid. He further recounted that snail meat contain a good blend of essential amino acids, such as lysine, leucine, isoleucine and phenylalanine. It is common in African traditional medicine to consume the bluish liquid collected from snail, calledhaemolymph due to the widespread belief of its potency in the treatment of certain ailments. Omole (2002) reported thathaemolymph is rich in copper and iron, which are important in oxidative phosphorylation and cellular energy production.

Nigeria is blessed with four breeds of snail; namely Archachatinamarginata, Achatinaachatina, AchatinafulicaandLimicolaria species: they are restricted to the southern part of Nigeria and the North center (Popoola, 2020 and Ademoluet al., 2004). All snail parts are useful, the foot is edible for human nutrition and shell is a good source of calcium and phosphorus in livestock nutrition, while the visceral mass is adopted in various animal feed 
industries as protein source. The proliferation of environmental related diseases, pollution, poor sanitation, and indiscriminate use of agrochemicals are detrimental to snail survival, growth and meat quality. Therefore, care must be taken to ensure that snail meat consumed is safe for human use.

Meat consumed must meet the standard safety threshold recommended for nutrients in order to avoid high dose of lethal nutrients and avoid nonnutritional ailments. The purpose of this trial is to evaluate the meat and haemolymph of Archachatinamarginata for its chemical contents. This is to avoid consequential effects from consumption of poisonous meat and haemolymph. This becomes very important with unregulated mining, oil pollution, and incessant disposal of waste. The information comes out from the present study will guide to the safe consumption of snail products.

\section{MATERIALS AND METHODS}

\section{Experimental animals:}

Forty-five growing snails (Archachatinamarginata) comprises 15 each of adults, growers and snailets were made available between March and September, 2019 (season of abundance and availability) from the open market in Ibadan, South west Nigeria. The market is the major snail market in the city and it is the location for the supply of snail to the final consumers.

The snails were properly conditioned before evisceratedfor haemolymph collection, while the carcass was disemboweled according to the procedure described by Lustrino et al. (2010) and Ademolu et al. (2009). Meat samples and haemolymph were collected in triplicates in the laboratory for chemical evaluation. Threeontogenetic stages (adults, growers and snailets) were considered for the chemical evaluation.

Proximate and Mineral analysis of snail meat:
Samples of snail meat were collected in triplicate for mineral and proximate determination. The proximate composition was determined by the method of A.O.A.C (1990), while the levels of calcium, magnesium and iron of snail meat were determined by means of Atomic Absorption Spectrometer (AAnalyst 200), while sodium, phosphorus and potassium were determined by using Flame photometry method (A.O.A.C. 1984).

\section{Chemical analysis of Haemolymph:}

This was carried out by modification of the methods described by Lustrino et al. (2010). The bluish haemolymph was collected by carefully opening the apex of the shells. The protein concentration was determined by Biuret method (Henry et al., 1974). The lipid assay was done following the method of Grant (1987) and the mineral content determination by the methods explained by Ademolu et al. (2009).

\section{Data analysis:}

The data obtained were subjected to Analysis of Variance (ANOVA) by the method of Steel and Torrie (1980), while the significant mean differences were separated by the method of Duncan's Multiple Range Test (Duncan, 1955).

\section{RESULTS}

Table 1 shows the proximate composition of the meat of snail at different growing stages, it elicited the dry matter, crude protein, ether extract, ashand nitrogen free extract. All parameters varied significantly $(p<0.05)$ in different growing snails, except the nitrogen free extract. Concentration of all parameters increased with growing stage of snail. Significantly $(\mathrm{p}<0.05)$ higher crude protein $(17.22 \%)$, ether extract (1.46\%) and ash (1.34\%) were recorded in adult snail, while least values were obtained for snailet.

Table 1. Proximate composition of the meat of African Land Snail (Archachatinamarginata) in relation to stages of growth

\begin{tabular}{lcccc}
\hline Parameters (\%dry weight) & \multicolumn{3}{c}{ Growing stages } & ISEM \\
\cline { 2 - 4 } & Adult & Grower & Snailet & 0.50 \\
\hline Dry matter & $79.25^{\mathrm{a}}$ & $78.93^{\mathrm{b}}$ & $78.39^{\mathrm{b}}$ & 0.50 \\
Crude protein & $17.22^{\mathrm{a}}$ & $16.30^{\mathrm{b}}$ & $15.83^{\mathrm{b}}$ & 0.15 \\
Ether extract & $1.46^{\mathrm{a}}$ & $1.35^{\mathrm{ab}}$ & $1.24^{\mathrm{b}}$ & 0.06 \\
Ash & $1.34^{\mathrm{a}}$ & $1.24^{\mathrm{b}}$ & $1.18^{\mathrm{b}}$ & 1.10 \\
Nitrogen Free Extract & 59.28 & 60.04 & 60.14 & 14 \\
\hline abc
\end{tabular}

${ }^{a b c}$ Means along the same row with different superscripts are significantly different $(\mathrm{P}<0.05)$.

Table 2 revealed the component levels of sodium, potassium, calcium, phosphorus, magnesium and iron of snail meat. The obtained values varied significantly $(\mathrm{p}<0.05)$ among different growing stages. The highest value was recorded for adult snail and the concentration was directly related to the age.
Highest sodium (44.75), potassium (92.24), calcium (42.19), phosphorus (295.64), magnesium (266.90) and iron (9.53) in $\mathrm{mg} / 100 \mathrm{~g}$ were recorded for adult snail, whereas least values for snailet. 
Table 2. Mineral composition of the meat of African Land Snail (Archachatinamarginata)in relation to stages of growth

\begin{tabular}{|c|c|c|c|c|c|}
\hline \multirow{2}{*}{$\begin{array}{l}\text { Parameters } \\
\text { weight) }\end{array}$} & \multirow[t]{2}{*}{ (mg/100g dry } & \multicolumn{3}{|c|}{ Growing stages } & \multirow[t]{2}{*}{ \pm SEM } \\
\hline & & Adult & Grower & Snailet & \\
\hline Sodium & & $44.75^{\mathrm{a}}$ & $39.57^{b}$ & $31.26^{\mathrm{c}}$ & 1.20 \\
\hline Potassium & & $92.34^{\mathrm{a}}$ & $77.55^{\mathrm{b}}$ & $69.24^{\mathrm{c}}$ & 2.34 \\
\hline Calcium & & $42.19^{\mathrm{a}}$ & $31.64^{\mathrm{b}}$ & $26.46^{\mathrm{c}}$ & 2.11 \\
\hline Phosphorus & & $295.64^{\mathrm{a}}$ & $286.65^{\mathrm{b}}$ & $274.50^{\mathrm{c}}$ & 1.71 \\
\hline Magnessium & & $266.90^{\mathrm{a}}$ & $246.70^{b}$ & $238.80^{c}$ & 1.23 \\
\hline Iron & & $9.53^{\mathrm{a}}$ & $7.37^{\mathrm{b}}$ & $5.25^{\mathrm{c}}$ & 1.48 \\
\hline
\end{tabular}

${ }^{\mathrm{abc}}$ Means along the same row with different superscripts are significantly different $(\mathrm{P}<0.05)$.

Table 3 illustrated the cholesterol profile of snail meat with variation $(\mathrm{p}<0.05)$ among the component fractions. Highest $(\mathrm{p}<0.05)$ total cholesterol $(18.33)$, HDL (2.06), LDL (3.30) and free fatty acids (12.97) in $\mathrm{mg} / 100 \mathrm{~g}$ were recorded for adult snail, the obtained values increased with the growing stage of snail.

Table 3. Cholesterol profile of the meat of African Land Snail (Archachatinamarginata) in relation to stages of growth

\begin{tabular}{lcccc}
\hline Parameters (g/dl) & \multicolumn{2}{c}{ Growing stages } & \multirow{2}{*}{ \pm SEM } \\
\cline { 2 - 4 } & Adult & Grower & Snailet & \\
\hline Total cholesterol & $18.33^{\mathrm{a}}$ & $13.50^{\mathrm{b}}$ & $11.59^{\mathrm{c}}$ & 2.07 \\
High Density Lipoprotein (HDL) & $2.06^{\mathrm{a}}$ & $1.96^{\mathrm{b}}$ & $1.97^{\mathrm{b}}$ & 0.12 \\
Low Density Lipoprotein (LDL) & $3.30^{\mathrm{a}}$ & $3.08^{\mathrm{a}}$ & $2.72^{\mathrm{b}}$ & 0.25 \\
Free Fatty Acids (FFAs) & $12.97^{\mathrm{a}}$ & $8.50^{\mathrm{b}}$ & $7.10^{\mathrm{c}}$ & 0.46 \\
\hline abc Means along the same row with different superscripts are significantly different $(\mathrm{P}<0.05)$ & &
\end{tabular}

${ }^{a b c}$ Means along the same row with different superscripts are significantly different $(\mathrm{P}<0.05)$.

From Table 4, it was revealed that mineral salts such as sodium, potassium, iron, magnesium copper, calcium and phosphorus present in snail haemolymph were not significantly $(\mathrm{p}>0.05)$ different among age groups.

Table 4. Mineral composition of the Haemolymph of African Land Snail (Archachatinamarginata) in relation to stages of growth

\begin{tabular}{lllll}
\hline Parameters (mg/100g) & \multicolumn{3}{c}{ Growing stages } & \pm SEM \\
\cline { 2 - 5 } & Adult & Grower & Snailet & 0.02 \\
Sodium & 0.10 & 0.09 & 0.08 & 0.03 \\
Potassium & 0.14 & 0.12 & 0.11 & 0.30 \\
Iron & 3.80 & 3.20 & 3.00 & 0.04 \\
Magnesium & 0.16 & 0.14 & 0.12 & 0.30 \\
Copper & 4.10 & 4.00 & 3.90 & 2.00 \\
Calcium & 45.00 & 44.00 & 43.10 & 0.50 \\
Phosphorus & 10.00 & 9.95 & 9.90 & \\
\hline
\end{tabular}

${ }^{\mathrm{abc}}$ Means along the same row with different superscripts are significantly different $(\mathrm{P}<0.05)$.

Table 5 further showed that cholesterol profile of snail haemolymph is highest in adult snail where total cholesterol (4.53 g/dl), HDL (1.20g/dl), LDL (0.70) and FFAs $(2.69 \mathrm{~g} / \mathrm{dl})$ were recorded.

Table 5. Cholesterol profile of the Haemolymph of African Land Snail (Archachatinamarginata) in relation to stages of growth

\begin{tabular}{lllll}
\hline Parameters (g/dl) & \multicolumn{3}{c}{ Growing stages } & \pm SEM \\
\cline { 2 - 5 } & Adult & Grower & Snailet & 2.07 \\
\hline Total cholesterol & $4.53^{\mathrm{a}}$ & $3.33^{\mathrm{b}}$ & $3.00^{\mathrm{c}}$ & 0.12 \\
High DensityLipoprptein (HDL) & $1.20^{\mathrm{a}}$ & $0.90^{\mathrm{b}}$ & $0.80^{\mathrm{b}}$ & 0.25 \\
Low Density Lipoprptein(LDL) & $0.70^{\mathrm{a}}$ & $0.65^{\mathrm{b}}$ & $0.59^{\mathrm{a}}$ & 0.46 \\
Free Fatty Acids (FFAs) & $2.63^{\mathrm{a}}$ & $1.78^{\mathrm{b}}$ & $1.61^{\mathrm{b}}$ & 0.10 \\
LDL-HDL differential & $0.50^{\mathrm{a}}$ & $0.25^{\mathrm{b}}$ & $0.21^{\mathrm{b}}$ & \\
\hline
\end{tabular}

${ }^{\mathrm{abc}}$ Means along the same row with different superscripts are significantly different $(\mathrm{P}<0.05)$.

\section{DISCUSSION}

The major source of snail in Nigeria is from the free-living snails rather to farmed snails and they are greatly imparted by the environmental soil and vegetation (Nyoagbe et al., 2016). The quality of the environment of snail cannot be predicted, since it is not from a controlled farm environment. Pollution is 
a great threat to the production of quality products from snail, due to the increase in fossil fuel combustion, mineral exploration and oil spillage (Ademolu et al., 2011 and Oladele-Bukola et al., 2020).

The human protein intake has become a critical issue that was considered by FAO (2011), in order to determine protein quantity and quality. It was emphasized that the amino acid quality is important in protein assessment of food items and snail inclusive. Several researchers have reported that snail meat is high in protein content, with component amino acids, cholesterol and cholesterol profile (Popoola, 2020).

The proximate assessment of snail meat elicited the dry matter, crude protein, ether extract, ash and nitrogen free extract. The meat is cherished, probably due to its low level of fat (1.24-1.46\%) and good quality protein (15.83-17.22\%), these outcomes aligned with the observation of Akinnusi et al. (2019) and Abiona et al. (2007). Its low level of fat could be the reason for its recommendation as a safe animal protein for people suffering from blood related ailments and kidney diseases (Omole, 2002).

The meat of snail is a tender delicacy, which is palatable and can be easily eaten by the elderly, without compromising their health. This view was also expressed by Kehinde (2009), when he reported that snail meat helps in promoting good health, reduce risk of chronic diseases and prevent clinical deficiencies in the elderly

The proximate parameters of snail meat were significantly $(p<0.05)$ different as the growth of snails advances. Mineral bioaccumulation is observed in the different ontogenetic stages and this has been related to ingested materials, such as soil and feedstuffs. The biosafety of snail meat can be inferred from its level of mineral ions, hence the determination of the concentration of sodium, potassium, calcium, phosphorus, magnesium and iron in snail meat.

Akinnusi et al (2019) reported that snail meat is richer in iron than the meat of broiler (1.25 $\mathrm{mg} / 100 \mathrm{~g})$, goat $(0.80 \mathrm{mg} / 100 \mathrm{~g})$ and Tilapia fish $(0.55$ $\mathrm{mg} / 100 \mathrm{~g})$. This is regarded as a rich source of iron for children and pregnant women in the rural and peri-urban areas (Imevbore and Ademosun, 1988). The evaluated mineral salts are important in cellular reactions as catalysts and in the regulation of cell osmotic balance. The evaluation also showed that snail meat is rich in phosphorus and potassium. In order to optimally explore the nutritional benefits of snail meat, there is need to screen for proximate parameters, to avoid the consumption of toxic meat. Snail meat had significantly $(\mathrm{p}<0.05)$ different levels of cholesterol, high density, lipoprotein low density lipoprotein and free fatty acids. The levels of cholesterol and component of fractions increased $(\mathrm{p}<0.05)$ from snailets to adults; this indicated that cholesterol is accumulated as the animal grows provided there is good feeding and absence of aggressors (biotic and abiotic factors). The highest level of total cholesterol $(18.33 \mathrm{mg} / 100 \mathrm{~g})$, HDL $(2.06 \mathrm{mg} / 100 \mathrm{~g})$, LDL $(3.30 \mathrm{mg} / 100 \mathrm{~g})$ and free fatty acids $(12.97 \mathrm{mg} / 100 \mathrm{~g})$ were recorded for adult snails. The prediction of the cholesterol quality is the level of HDL, which is highest $(\mathrm{p}<0.05)$ in adult and LDLHDL differential which is least in snailets. Physiologically, the HDL is helpful in prevention of blood clotting by demobilizing fat from blood vessels, while for consumption the snailet is preferred, because of its low level of LDL-HDL differential.

Archachatinamarginata, like other snails, have open circulatory system, with all their internal organs birth in a bluish fluid called haemolymph, which is widely consumed fresh for the treatment of different ailments (Odaebo et al., 2000). The mineral content of the fluid was evaluated and was not influenced by stages of growth, this was also reported by Lin et al (2006) and Alabi et al (2015). The levels of sodium, potassium, iron, magnesium, copper, calcium and phosphorus in all growing stages differed nonsignificantly).

The lifecycle assessment of the cholesterol of snail haemolymph was carried out because of its implication in many blood related diseases, such as hypertension, heart failure and kidney ailments.

The cholesterol of the haemolymph was highest $(p<0.05)$ in adults and least in snailets, all components of cholesterol were significantly different and within safe range as reported by Omole (2002).

\section{CONCLUSION}

The general assessment of the meat and haemolymph of African giant land snail (Archachatinamarginata, Swinson) revealed higher concentration of mineral salts and cholesterol in the meat; while their life cycle evaluation established increased mineral and cholesterol accumulated as the snail growth advances. It looks like thatsnail meat andhaemolymphas revealed by the current study contained important nutrients for human nourishment and other consumptive applications.

\section{ACKNOWLEDGEMENT}

I want to acknowledge the support of the Department of Wildlife and Ecotourism of Forestry Research Institute of Nigeria for providing the needed facilities for the successful execution of this research.

\section{Authors' contribution:}

Kehinde AS drafted the manuscripts, procured the snails for the research, Adelakun KM and Fadimu BO conducted the laboratory analysis, while Babatunde TO and Halidu SKsearch the literature, revised and corrected the manuscript. Final manuscript was read and approved by all authors for publication. 


\section{REFERENCES}

A.O.A.C. 1984.Official methods of Analysis.Vol 1, $15^{\text {th }}$ edition Arlinta, V.A

A.O.A.C.1990. Association of official Analytical chemist, Ed.WHorwitz 13th edition Washington D.C P1141

Abiona, J.M., O.A. Osmowo, M.A. Ozoje, D. Eruvbetine and M.O. Abiona., 2007. Differences in the spermatozoa and Ova of two species of giant African land Snail. Nigerian Journal of Animal production 34: (1\&2):306-315.

Ademolu K.O., D.O. Olasupo, A. Oropo and O. Akinnusi., 2020. Heavy metals concentrate in the fresh water Snails, LanistersLubicus collected from the Federal university of Agriculture Abeokuta South western Nigeria. Journal of Molluscan Research 6:65-70.

Ademolu, K.O., A.B. Idowu, C. Mafiana and O.A. Osinowo.,. 2004. Performance, proximate and mineral analysis of African giant land snail (Archachatinamarginata) fed different nitrogen sources. African Journal of Biotechnology, 3(8): 412-417.

Ademolu, K.O.,A.B. Idowu and O.A. Jayeola., 2009. Changes in haemolymph biochemical values during different phases of growth of African giant land snail. (Archachatinamarginata Swainson). Nigeria Journal of Animal Production 36:161166.

Ademolu, K.O., O.A. Jayeola,G.A. Dedeke, and A.B. Idowu., 2011.Comparative analysis of growth performance and haemolymph biochemical properties of normal and albino giant land Snail. Archachatinamarginata. Ethiopian Journal of Environmental Studies and Management 4:101106

Akinloye, O.A. and O. Olorede., 2000. Effects of different feeding conditions on performance, haemolymph biochemical and mineral value of Giant African snail (Archachatinamarginata), Journal of Agriculture and Environment 1:143147

Akinnusi, O, O.O. Oni, and K.O. Ademolu., 2019. Variation in chemical composition of shell and haemolymph of Giant Land Snail Archachatinamarginata, during wet and dry seasons in Nigeria.Journal of Molluscan Research.5:31-36

Alabi J.O., A.O. Fafiolu, A.A.O. Ekemezie, and C.G. Alimba., 2015.Absorbtion and bioaccumulation of heavy metals in African giant land Snail (Archachatinamarginata) in the Bulleton of Animal health and production in Africa. 63 (4):115-120

Duncan, D.B., 1955. Multiple Range and multiple F. test Biometrics 11:1-42.

Ebenebe, C.I., 2000. Mini-livestock productionin Nigeria.The present and the future. In:Proceedings of the 5th Annual Conference, (ASAN), (pp. 19-22). Port Harcourt, Nigeria.
F.A.O., 2006.Food and AgriculturalOrganization of United Nations. The state of food insecurity in the world.Taking stock ten years after the world food summit.http//www.fao.org.

F.A.O., 2010.Food and Nutrition on fat and fatty acid in human nutrition. Report of expert consultation. Rome, FAO. P51.

F.A.O., 2011. Expert consultation on protein quality evaluation held in Auk land, New Zealand on March 31- April 2, 2011.

Grant, G.H., 1987. Fundamentals of clinical chemistry. USA: WB Saunders Company.

Henry, R.J,,D.C. Canon, and J.W. Winkalman., 1974. Clinical chemistry.Principle and Technique 2nd ed. Harper and Row Publishers.New York pp5456.

Imevbre, E.A. and A.A. Ademosun., 1988.The nutritive value of the African giant land Snail.Journal of Animal production resource. 8(2):76-78.

Kehinde, A.S., 2009. Utilization of Cassava (ManihotesculentaCrantz) by-products by African land snail (ArchachatinamarginataSwaison). A Phd thesis submitted to the University of Ibadan, Dept of Animal science P.146.

Kehinde, A.S., 2019. Wealth creation and employment generation through Snail production and research. Journal of Molluscan Research.5:13.

Lin, E, V. Enobakhare, and I. Ilechie., 2006. Bioaccumulation of heavy metals $(\mathrm{Cu}, \mathrm{Zn}, \mathrm{Fe})$ in fresh water Snail (Pilaovata) from Ikpobariver of southern Nigeria. Journal of Aquatic Sciences21: 23-28.

Lustrino D., V.M. Tunholi-Alves,V.M. Tunholi,M.P. Marassi, and J. Pinheiro.,2010. Lipid analysis in haemolymph of African giant Achatinafulica (Bowdich, 1822) exposed to different photoperiods.Brazil Journal of Biology70 (1): 129-134.

Manary M., 2013. Inadequate dietary protein intake: when does it occur and whatare the consequences? Food and Nutrition Bulletin, Vol. 34(2): 247-248.

Nyoagbe, L.A., V. Appiah, J. Nketsia-Tabiri, D. Larbi, and I. Adjei., 2016. Evaluation of African giant snails (Achatina and Achachatina) obtained from market (wild) and breeding farms. African Journal of Food Science, Vol. 7: 94-104

Odaibo, A.B., A.J.Dehinbo, L.K.Olofintoyeand O.A. Falode., 2000. Occurrence and distribution of Rhabditida: Rhabditidae) in African Giant Snails in South western Nigeria Heminthologia 37(4):233-235.

Oladele-Bukola M.O., A.S. Kehinde, O.S. Banjoko, T.A. Olakojo, A.A. Bolaji, A.S. Durotoye, and A.J. Omole., 2020. Growth performance of Snails (Archachatinamarginata) fed diets containing Snail shell. Journal of Molluscan Research6: 7985.

Omole, A.J., 2002. Nutrients requirements for different stages of growth of African giant Snail 
(Archachatinamarginata) $\mathrm{PhD}$ thesis submitted at the dept of animal science, University of Ibadan. P2.

Ososanya, T.O., 2004. Chemical composition and dry matter digestibility of broiler litter based diet in West African Dwarf sheep. The annual proceedings of ASAN pp115-117.
Popoola, Y.A., 2020. Performance and cost benefits of Snails fed diet containing varying levels of African Yam Bean meal. Journal of Molluscan Research6:23-29.

Steel, R.G. and J.H. Torrice., 1980.Principles and procedures of statistics, $2^{\text {nd }}$ ed. Mc Grass- Hill Book co, New York, U.S.A. P633.

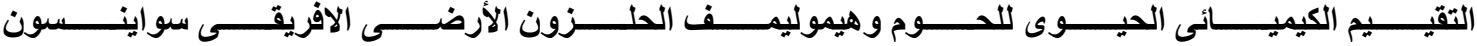 فى جنوب غرب نيجيريا (Archachatinamarginata, Swainson)}

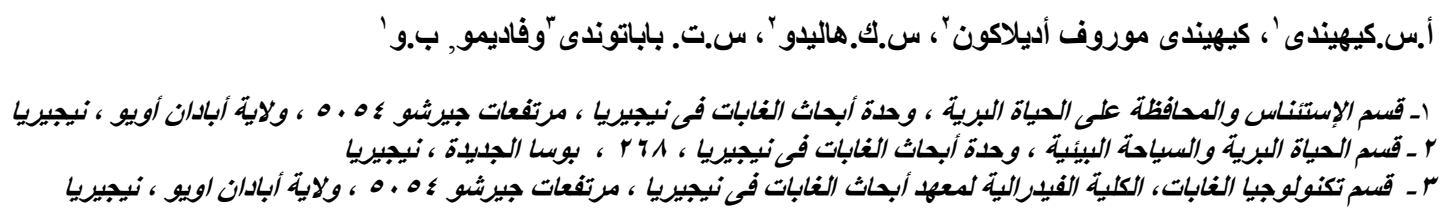

تم تخصيص خمسة واربعون حلزوناً أرضياً أفريقياً (Archachatinamarginata, Swainson) بشكل عشو ائي لثنلاث معاملات (البالغة,

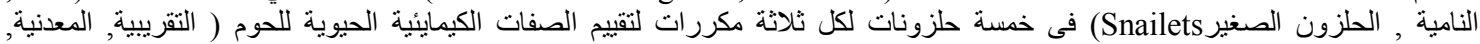
الكوليسترول) و الهيموليمف النغير (معادن وكوليسترول).

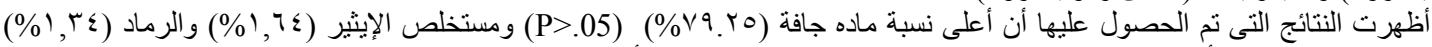

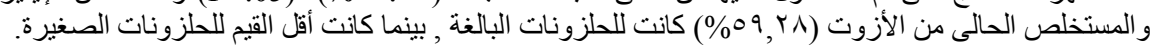

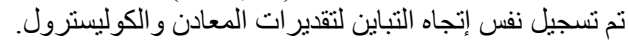

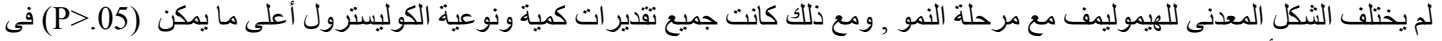

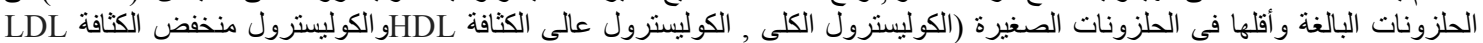
و الكوليسترول الداخلى LDL-HDL. تحنوى لحوم و هيموجلو بين الحلزون في منطقة الدر اسة على مغذيات مهمة لتغذية الإنسان وللأغر اض الإستهلاكية الأخرى. 